DOI https://doi.org/10.18551/rjoas.2017-11.60

\title{
IMPROVING QUALITY AND QUANTITY OF ONIONS YIELDS IN MOUNT MERAPI ERUPTION SOIL WITH VARIOUS SOURCES OF POTASSIUM AND SULFUR
}

\author{
Astiningrum Murti*, Suprapto Agus, Historiawati \\ Faculty of Agriculture, University of Tidar, Indonesia \\ ${ }^{\star}$ E-mail: murti astiningrum@yahoo.com
}

\begin{abstract}
This research was conducted on post-eruption land area near Mount Merapi in Central Java Indonesia with the addition of goat manure of 30 tons/ha using factorial experiment prepared in Randomized Block Design (RAKL), with two treatment factors, and the treatment was repeated three times. The first factor was the source of potassium: no potassium, $\mathrm{KCl}, \mathrm{KNO}_{3}$. Second factor source was Sulfur: without sulfur, ZA, Petro-Cas. The data were analyzed by variance, if there is real difference followed by LSD test $1 \%$. The results show that (1) Fertilization of $\mathrm{KNO}_{3}$ and $\mathrm{ZA}\left(\mathrm{NH}_{4}\right) 2 \mathrm{SO}_{4}$ in onion plants shows the highest yield on fresh weight of onion tubers per clump and per square meter; (2) Fertilization of $\mathrm{KNO}_{3}$ without the addition of sulfur to obtain dry weight of the lowest weight of onion tubers per clump and per square meter; (3) Fertilization of $\mathrm{KCl}$ and $\mathrm{ZA}\left(\mathrm{NH}_{4}\right) 2 \mathrm{SO}_{4}$ on onion plant causes the highest water content on dried onion tubers; and (4) Fertilization of $\mathrm{KCl}$ and Petro-Cas $\left(\mathrm{CaSO}_{4}\right) 2 \mathrm{H}_{2} \mathrm{O}$ on onion plants yields the highest number of essential oil.
\end{abstract}

\section{KEY WORDS}

Onions, sulfur, potassium, yield, soil.

Production of food crops and horticulture is a primary need for the Indonesian society so that this is necessary to strived in order to meet domestic production. The conversion of agricultural land into non-agricultural land, however, obviously reduces the planting area in Indonesia. Despite the Spatial Plan (RPLW) or a Regional Regulation occur in managing land use, including the land conversion, the decrease of planting area cannot be avoided due to vast national development. Therefore, one of possible effort is to improve the quality of existing agricultural land with a variety of engineering in order to produce food with a better quality and quantity, as well as with high economic value.

This study focuses on land near Sawangan sub-district, Central Java, affected by eruption of Mount Merapi in 2010. Most of the land has been reforested with various food crops and horticulture, but the production of food crops and horticulture grown by farmers has not been able to prosper their life; the more land are leased to seed entrepreneurs and farmers from outside the region. In order for the landowners to work on their land, special strategies are needed to obtain methods that can increase food production and selection of crops. Onion (Allium cepa L.) is one type of commodity that has significance for the community, both seen from the economic value and nutritional content.

\section{METHODS OF RESEARCH}

The research was conducted in post-eruption land near Mount Merapi in Central Java with the addition of goat manure 30 tons/ha using factorial experiment prepared in Randomized Completely Randomized Block Design (RAKL) with two treatment factors, and the treatment was repeated three times. The factors were:

Factor 1: Potassium (K) source:

- K0: without potassium

- $\mathrm{K} 1: \mathrm{KCl}$

- $\mathrm{K} 2: \mathrm{KNO}_{3}$

Factor 2: Sulfur (S) source:

- S0: without sulfur 
- S1: $\mathrm{ZA}\left(\mathrm{NH}_{4}\right)_{2} \mathrm{SO}_{4}$

- S2: Petro-Cas $\left(\mathrm{CaSO}_{4}\right)_{2} \mathrm{H}_{2} \mathrm{O}$

Of the factors above, it was obtained nine combinations of treatments, each of which was repeated three times with the following scenario:

$$
Y_{i j k}=U+A_{k}+B_{i}+T_{j}+E_{i j k}
$$

Where:

$\mathrm{Y}_{\mathrm{ijk}}$ : observation score on the treatment number $i$ and $j$ and group to $k$;

$\mathrm{U}$ : general median;

$A_{k}$ : the influence of treatment number $k$;

$B_{i}$ : the influence of treatment number $l$;

$\mathrm{T}_{\mathrm{j}}$ : the influence of treatment number $j$;

$E_{i j k}$ : trial error on the treatments of $i, j$, and group number $k$;

The data obtained were analyzed by using variance, and the treatment was continued to LSD if the significance level is $1 \%$.

\section{RESULTS AND DISCUSSION}

Table 1 shows that the results of analysis of fertilization treatments from various sources of potassium and sulfur which do not show the difference on the parameters of both fresh weight and dry weight of tubers per square meter, fresh weight and dry weight per square meter, the essential oil content. On the other hand, the parameter of water content of dry onion tubers is very distinct on the block.

Table 1 - Analysis results of observation on onion plants

\begin{tabular}{llll}
\hline Observation parameters & Block & Treatments \\
\hline 1 & Fresh weight of tuber per clump & $1.1550^{\mathrm{ns}}$ & $0.4690^{\mathrm{ns}}$ \\
2 & Dry weight of stored onion tubers per clump & $1.3060^{\mathrm{ns}}$ & $0.7210^{\mathrm{ns}}$ \\
3 & Fresh weight of tubers per square meter & $1.7898^{\mathrm{ns}}$ & $0.8112^{\mathrm{ns}}$ \\
4 & Dry weight of stored onion tubers per square meter & $2.3900^{\mathrm{ns}}$ & $1.1180^{\mathrm{ns}}$ \\
5 & Water content of dried tubers & $4.0554^{\mathrm{n}}$ & $1.5612^{\mathrm{ns}}$ \\
6 & Essential oil content of onions & $1.411^{\mathrm{ns}}$ & $1.118^{\mathrm{ns}}$ \\
\hline
\end{tabular}

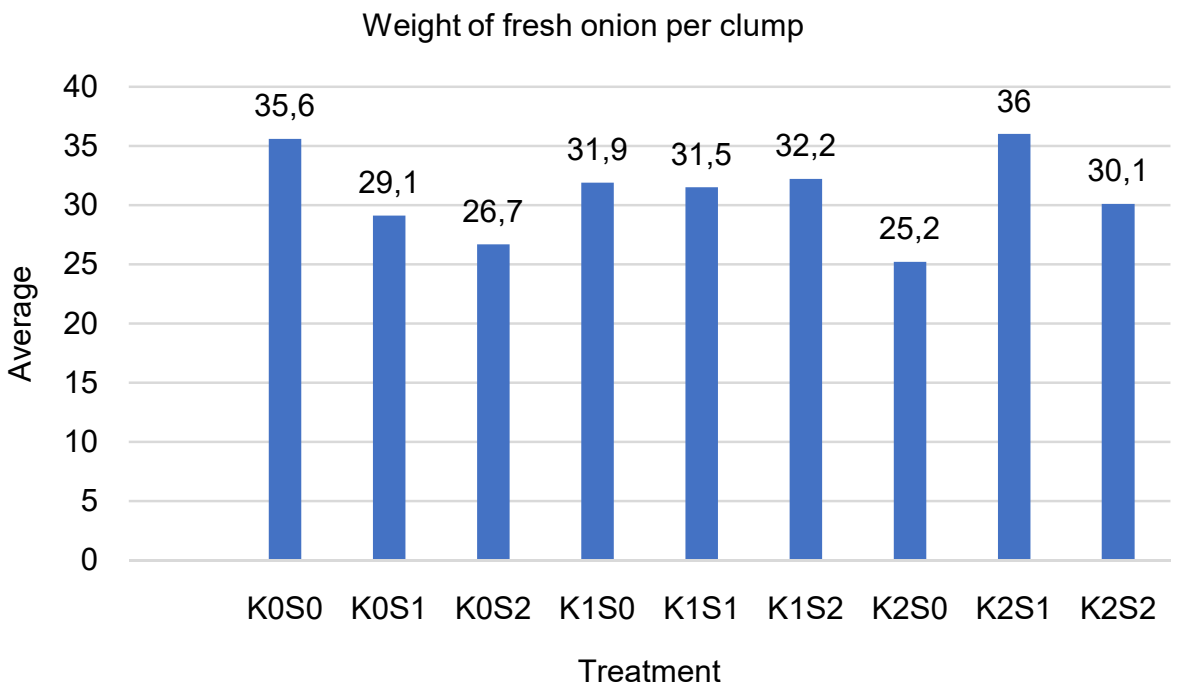

Figure 1 - Diagram of average weight of fresh onion tubers per clump

In Figure 1, the average weight of fresh onion tubers per clump on the treatment with $\mathrm{K}_{2} \mathrm{~S}_{1}$ (the addition of $\mathrm{KNO}_{3}$ and $\left.\mathrm{ZA}\left(\mathrm{NH}_{4}\right) 2 \mathrm{SO}_{4}\right)$ shows the highest yield, i.e. 36 grams. 
Similarly in Figure 2, the diagram of weight of fresh onion tubers per square meter, weighing $1,044.5$ grams.

The high weight of fresh onion tubers on the $\mathrm{K}_{2} \mathrm{~S}_{1}$ treatment is caused the nitrogen uptake in the form of nitrate $\left(\mathrm{NO}_{3}\right)$ and ammonium $\left(\mathrm{NH}_{4}\right)$ from the treatment. Nitrate is the most preferred substance for most plant's growth. The ammonium uptake occurs best on neutral medium and decreases as the decreasing $\mathrm{pH}$. On the other hand, nitrate uptake is faster at lower $\mathrm{pH}$, and the higher uptake occurs if both $\mathrm{N}$ forms are in soil solution. The changes of nitrate into $\mathrm{N}$ form are reduced after being inside the plant tissue and require energy, and the energy conservation occurs during the absorption process of $\mathrm{N}$ as ammonium which is used in metabolic processes, including for ion absorption and plant growth, increasing the weight of fresh onion tubers either per clump or per square meter.

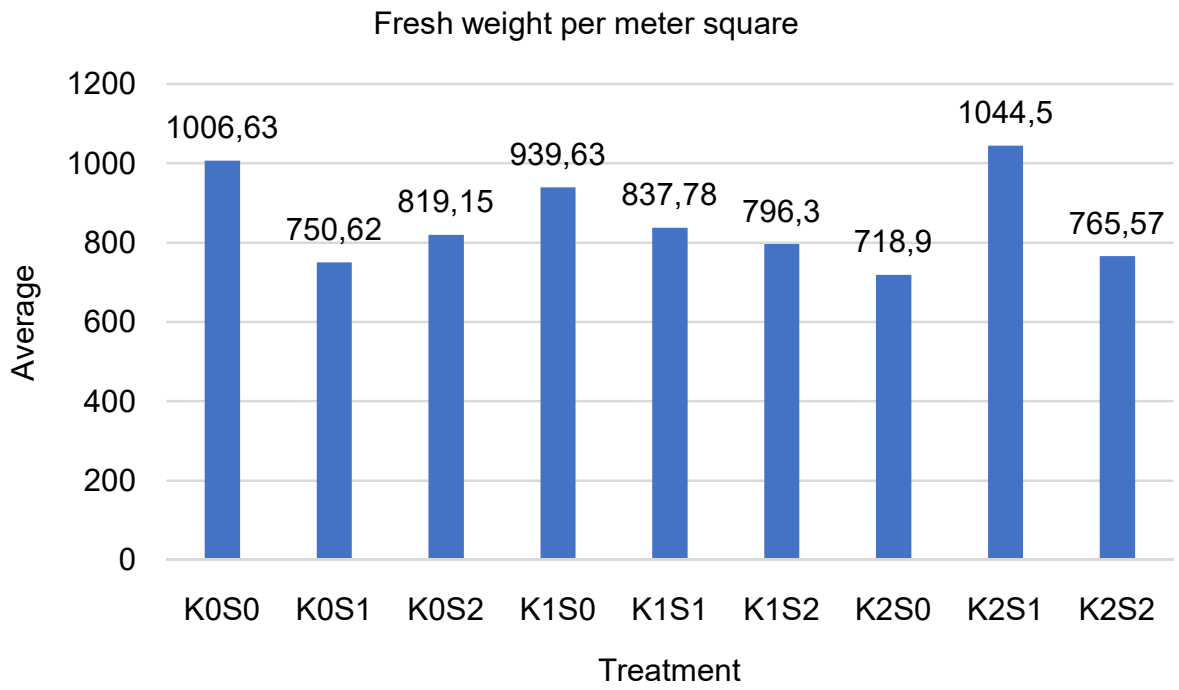

Figure 2 - Diagram of the average weight of fresh onion square meter

The sufficiency of potassium in plants will facilitate photosynthesis since the potassium in the plant body has some functions, namely: a) as an activator of some enzymes, b) related to the regulation of water and energy, c) playing a role in protein and starch synthesis, and d) photosynthate removal. Photosynthate as a result of photosynthesis will be transported from the leaf to the places where it is needed, either for the use or storage. The potassium element is essential in photosynthesis process as it is involved in the synthesis of ATP, the production in the activity of photosynthetic enzymes, the absorption of $\mathrm{CO}_{2}$ through the mouth of the leaves and maintaining the electrical balance during photophosphorylation in chloroplasts, besides potassium is also involved in transporting photosynthesis results from leaves through phloem to tissues of reproduction and storage organs (fruit, seeds, and tubers). In fruit and vegetable crops (oranges, bananas, tomatoes, potatoes, and onions), potassium supply can improve the size, color, taste and fruit skin, which is important for storage and transport, this also causes the addition of potassium from fertilization of $\mathrm{KNO}_{3}$ can increase fresh weight of onion tubers.

Plants with high sulfur content are legume and Lileaceae (including onions). Sulfur is an important constituent of all proteins, some plant hormones, vitamins and enzymes, oilmustard glycosides and glutathione and essential for the formation of chlorophyll, so that the addition of sulfur can activate the process of photosynthesis, which in turn will increase the weight of onions either per clump or per square meter.

Figures 3 and 4 show that the treatments with $\mathrm{K}_{2} \mathrm{~S}_{0}$ (with the addition of $\mathrm{KNO}_{3}$ without the addition of sulfur) obtained the lowest stored weight of dry onions, namely 16.375 grams per clump and 452.17 grams per square meter. 


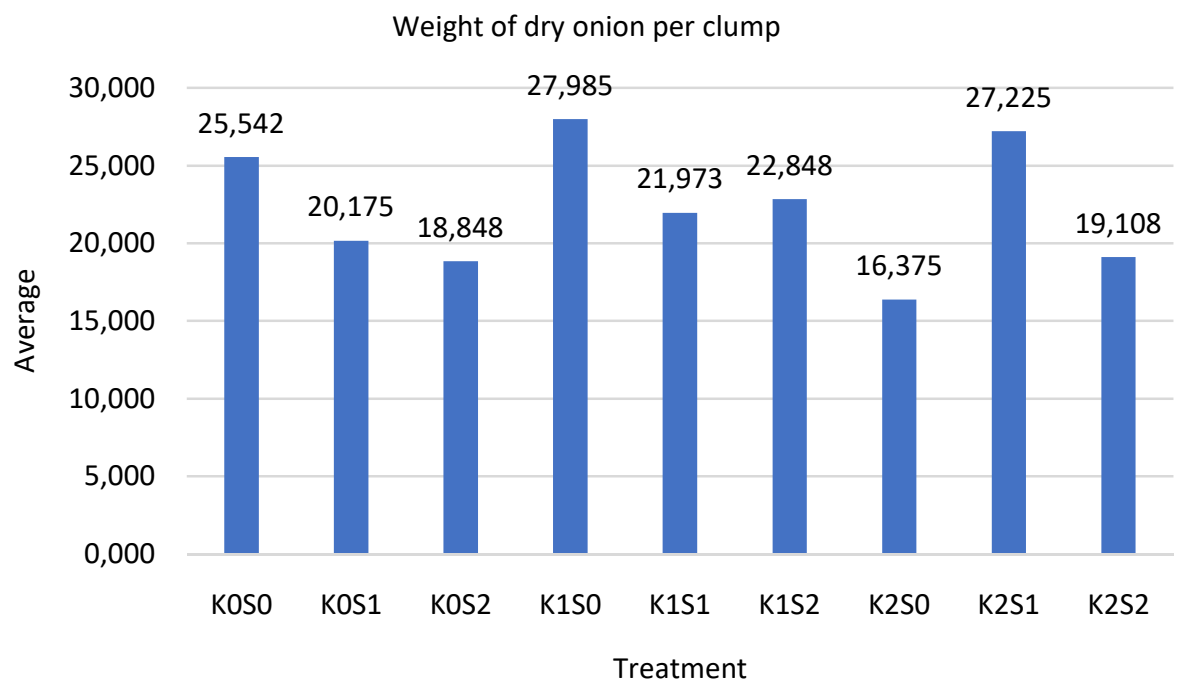

Figure 3 - Diagram of the average of stored weight of dry onions per clump

Potassium heightens the movement of photosynthate out of the leaves to the roots, and it will increase the provision of energy for the root growth and the development of fruits in terms of size and quality. In addition, the provision of potassium in large number increases the amount of stomata per unit of leaf area. In short, the increased supply of potassium supported with the favorable moisture conditions will increase the opening of stomata, thus affecting photosynthesis which will ultimately boost adequate results.

Plants require sulfur as much as phosphate elements, about $0.1 \%$ to $0.5 \%$ distributed to all parts of the plant. High sulfur content can be found in plants that produce mustard oil with distinctive odors and flavors in plant species of the Cruciferae family, such as cabbage, cabbage and Lileaceae family plants, such as onions, garlic, and asparagus. Typical flavors and odors in both plant families are due to the presence of volatile $S$ compounds. Even though the compound is not the constituent, $S$ also affects the formation of chlorophyll and the synthesis of carbohydrates, so the $S$ deficiency influences the color of the leaves (turning into yellow color) and the dry weight of the onions becomes lower.

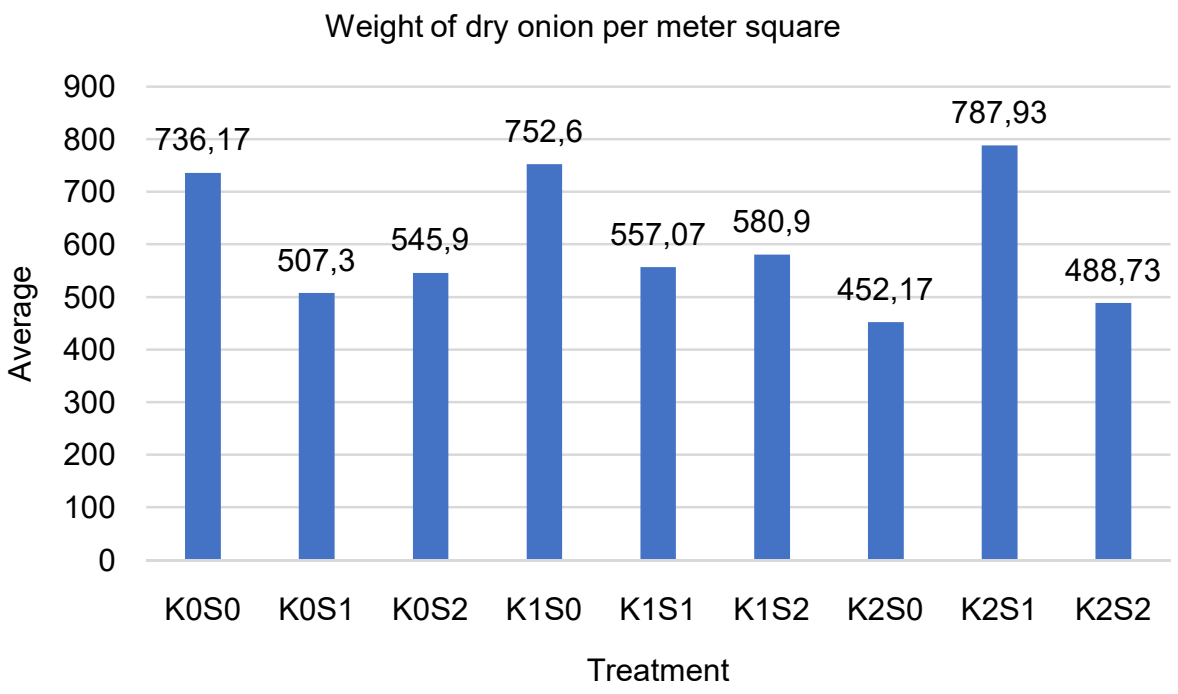

Figure 4 - Diagram of the average weight of dry onions per square meter 
Figure 5 shows that treatment with $\mathrm{K}_{1} \mathrm{~S}_{1}$ (with the addition of $\mathrm{KCl}$ and $\mathrm{ZA}\left(\mathrm{NH}_{4}\right) 2 \mathrm{SO}_{4}$ ) affects the stored weight of dry onions tubers containing the highest water content of $90.51 \%$.

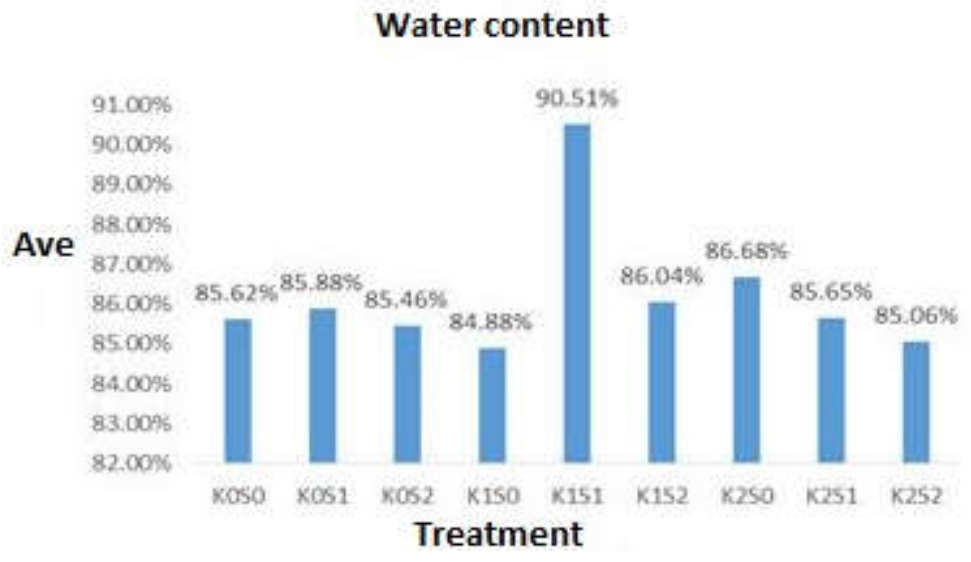

Figure 5 - Diagram of water content in the stored dry onion tubers (\%)

Fertilization of $\mathrm{N}$ in the form of nitrate causes the absorption of $\mathrm{Cl}$ decreased since both are negative, while fertilization of $\mathrm{N}$ in the form of ammonium causes $\mathrm{Cl}$ uptake increasing. Chlor acts as a plant nutrient, $\mathrm{Cl}^{-}$ion has a role of protoplasm bubbling and increasing cell permeability. The role of cell turgor is almost the same as the $\mathrm{K}$ ion, which increases the osmoses pressure of the cell. Chlor also plays a role in the cell's water system, preventing unbalanced water loss and causing the addition of ammonium from ZA fertilizer plus $\mathrm{KCl}$ fertilization which cause an increase of $\mathrm{Cl}$ in plants and increase water content in onions.

Figure 6 shows that the treatment with $\mathrm{K} 1 \mathrm{~S} 2$ (with the addition of $\mathrm{KCl}$ and Petro-Cas $\left(\mathrm{CaSO}_{4}\right) 2 \mathrm{H}_{2} \mathrm{O}$ fertilizer on onion plants) yields the highest essential oil content (which is often called mustard oil) of $13.133 \%$, which means there is an increase of more than $100 \%$ of essential oil content of the planted seeds $(6.2 \%)$.

Loss of sulfur from the soil is partly due to overlapping as sulfate, especially on sandy soil. The land area used for the study is typical sandy soil that allows sulfate removal. Onion plants require considerable sulfur, comparable to phosphate requirements so as to be highly responsive to sulfur fertilization derived from Petro-Cas. This is indicated by the highest increase in essential oil content, and in accordance with the opinion of Havlin et al (2005) who states that the high $S$ content found in plants produces mustard oil with distinctive smells and flavors.

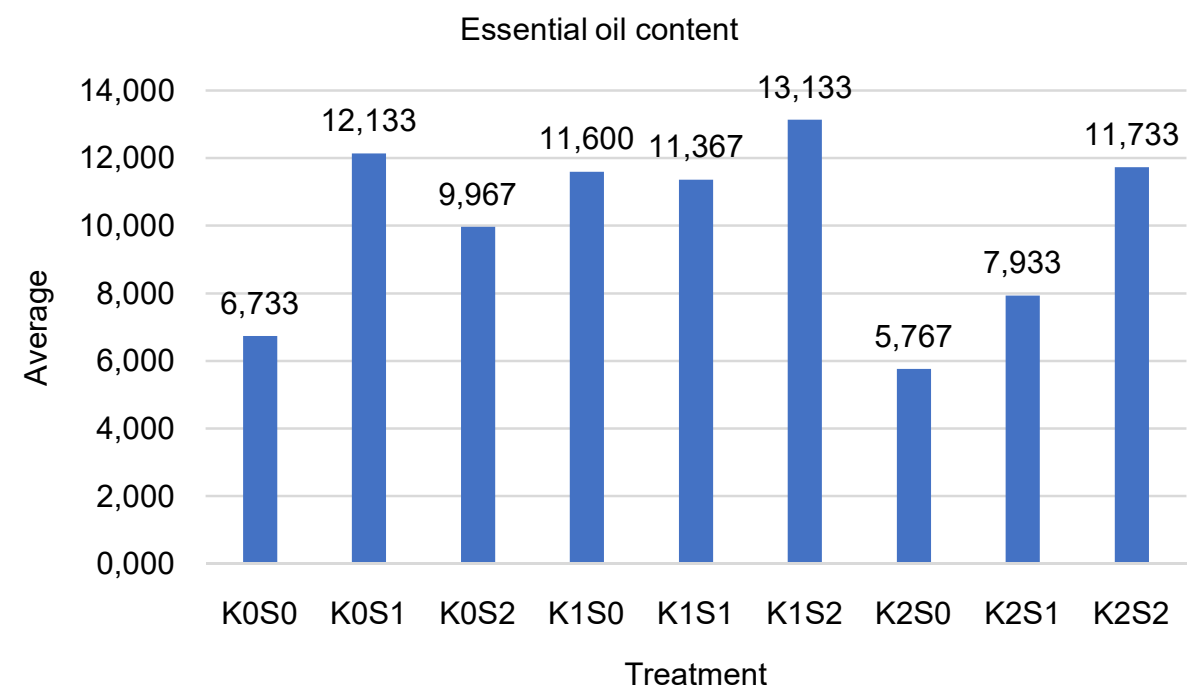

Figure 6 - Diagram of essential oil content in onion tubers (\%) 
The roles of sulfur in plant growth and metabolism are namely (1) for the synthesis of amino acids containing S, such as Cystine, Cysteine and Methonine and also for protein synthesis, so that $S$ deficiency can lead to inhibition of protein preparation, which is amino acids; (2) activating certain proteolytic enzymes such as papainase, papain, bromelin and ficin; (3) being part of certain vitamins, coenzym A and glutathione; (4) increasing in-plant oil content such as soybeans; and (5) also available in oils of some plans such as spices and onions (Havlin et al, 2005).

\section{CONCLUSION}

Corroborating the analysis of all relevant parameters, it is concluded that:

By looking at the analysis of all parameters, it is concluded:

Fertilization of $\mathrm{KNO}_{3}$ and $\mathrm{ZA}\left(\mathrm{NH}_{4}\right) 2 \mathrm{SO}_{4}$ in onion plants shows the highest yield on fresh weight of onion tubers per clump and per square meter;

Fertilization of $\mathrm{KNO}_{3}$ without the addition of sulfur is to obtain the lowest dry weight of onion tubers, both in terms of weight per clump and per square meter;

Fertilization of $\mathrm{KCl}$ and $\mathrm{ZA}(\mathrm{NH} 4) 2 \mathrm{SO}_{4}$ on onion plants causes the highest water content on dry weight of stored onion tubers; and

The fertilization of $\mathrm{KCl}$ and Petro-Cas $(\mathrm{CaSO} 4) 2 \mathrm{H}_{2} \mathrm{O}$ on onion plants yields the highest essential oil.

\section{REFERENCES}

1. Anonymous. 2011. Luas Panen, Produksi dan Produktivitas Bawang Merah. http://www.bps.go.id. Center of Statistic Agency. Accessed at 7 July 2014.

2. Astiningrum, Murti, Historiawati \& Tujiyanta. 2014. Increasing Production Land of Mount Merapi Eruption for the Cultivation of Apomoea reptans. Report of Competitive Grant I. Faculty of Agriculture, UNTIDAR, Magelang.

3. Astiningrum, Murti, Historiawati \& Tujiyanta. 2015. Increasing Production Land of Mount Merapi Eruption for the Cultivation of Apomoea reptans. Report of Competitive Grant II. Faculty of Agriculture, UNTIDAR, Magelang.

4. Astiningrum, Murti, \& Historiawati. 2016. Increasing Production Land of Mount Merapi Eruption for the Cultivation of Apomoea reptans. Report of Competitive Grant III. Faculty of Agriculture, UNTIDAR, Magelang.

5. Havlin JL, Beaton JD, Nelson WL. 2005. Soil Fertility and Fertilizers. An Introduction to Nutrient Management. New Jersey: Pearson Prentice Hall.

6. Muhlizah, F. \& S. Hening-S. 2000. Sayur dan Bumbu Dapur Berkhasiat Obat. Jakarta: Penebar Swadaya.

7. Purwanto, 2010, Pemulihan Lahan di Kawasan Merapi, www.kr.co.id., Accesed at 27 January 2014.

8. Rajiman. 2009. Pengaruh Pemupukan NPK Terhadap Hasil Bawang Merah di Lahan Pasir Pantai. Jurnal IImu-IImu Pertanian. (5) 1: pp. 52-60.

9. Rubatzky, V. E. \& M. Yamaguchi, 1998. Sayuran Dunia 2 Prinsip, Produksi, dan Gizi. ITB, Bandung.

10. Rukmana, Rahmat. 2005. Bawang Merah : Budidaya dan Pengelolaan Pasca Panen. Kanisius. Yogyakarta.

11. Suprapto, Agus, Historiawati \& Murti Astiningrum. 2015. Pemanfaatan Mikoriza dan Pupuk Organik terhadap Hasil Bawang Merah (Allium cepa fa. Ascolanicum) pada Lahan Pasir erupsi Merapi. Laporan Penelitian Hibah Bersaing.

12. Suprapto, Agus \& Tujianta. 2016. Peningkatan Hasil Bawang Merah (Allium cepa fa. Ascolanicum, L.) Dengan variasi pupuk organik dan Jarak Tanam Di Lahan Pasir Erupsi Merapi. Laporan Penelitian Hibah Bersaing.

13. Wibowo, S. 2009. Budidaya Bawang Putih, Bawang Merah dan Bawang Bombay. 